\title{
ПРОКУРОР ЯК ПРЕДСТАВНИК ІНТЕРЕСІВ ГРОМАДЯН ТА ДЕРЖАВИ В СУДІ: ДОСВІД КРАЇН ЕВРОСОЮЗУ
}

БОРТНИК Надія Петрівна - доктор юридичних наук, професор, завідувач кафедри адміністративного та інформаційного права Національного університету «Јьвівська політехніка"

ORCID 0000-0003-1794-2793

ВІТИК Орест Дмитрович - здобувач кафедри адміністративного права i процесу, фінансового права, інформаційного права Приватного вищого навчального закладу «Львівський університет бізнесу та права»

УДК 347.963

DOI 10.32782/EP.2021.8

B статье проанализированы законодательное закрепление функиии представительства прокуратурой интересов гражданина или государства в суде в странах СНГ и Евросоюза. Рассмотренъ изменения оснований $и$ порядка осуществления прокурором представительской деятельности в соответствии с Законом Украинъ «О прокуратуре» от 14 октлбря 2014 года.

Сделан въъвод, что функиия представительства, которой наделена прокуратура Украинъ, в современньх условиях является вполне обоснованной и оправданной, о чем свидетельствуют результать многолетней практической деятельности прокурора по защзите прав граждан и интересов государства в суде.

Отмечено, что во многих странах Европь наряду с главной фбнкиией прокуратурь - осуществлением уголовного преследования - значительное внимание уделяется защите прав и свобод граждан и интересов государства в суде. В частности, такая деятельность органов прокуратуры предусмотрена законодательством в странах Евросоюза - Бельгии, Болгарии, Латвии, Аитве, Польше, Португалии, Словакии, Венгрии, Испании, Франции. Указанная деятельность полностью соответствует европейским правовым традициям зашить прав и свобод человека в странах Европейского Союза.

Ключевъие слова: прокуратура, зашита прав, фуункиии, представительство интересов, граждане, государство, суд.

\section{Постановка проблеми}

У Конституції України закріплено, що на органи прокуратури покладено функцію представництва інтересів громадянина або держави в суді. У країнах Західної Европи немає єдиного підходу щодо визначення функцій органів прокуратури. Кожна держава Евросоюзу встановлює роль, місце і завдання прокуратури 3 урахуванням національних інтересів, конституційних традицій та стану правової культури суспільства. Прокуратура реалізує функцію представництва інтересів громадянина або держави у суді лише у межах визначених процесуальних правовідносин. Водночас на сьогодні практично не вирішеним залишається питання щодо процесуального правового статусу прокурора як учасника судового процесу, що безпосередньо реалізує зазначену функцію [1, с. 115].

Стан дослідження проблеми

Різноманітні аспекти правового статусу державних органів, зокрема, i прокуратури, досліджуються у працях багатьох видатних науковців: О. Бандурки, $\lambda$. Грицаєнка, Ю. Грошевого, Л. Давиденка, В. Долежана, П. Каркача, М. Косюти, М. Курочки, I. Марочкіна, О. Михайленка, М. Мичка, Е. Поповича, Н. Рибалки, М. Руденка, В. Сухоноса, В. Тація, Ю. Тодики, Ю. Шемшученка, П. Шумського, М. Якимчука та ін.

Виклад основного матеріалу

Прийняття Закону України «Про прокуратуру» (2014 р.) [2] та внесення ним змін 
до процесуального законодавства суттєво реформують механізм реалізації прокуратурою України функції представництва інтересів громадянина або держави в суді, що зумовлює потребу у додаткових дослідженнях загальнометодологічних питань правового статусу прокуратури як суб’єкта реалізації функції представництва інтересів громадянина або держави в суді [1, с. 115].

Насамперед необхідно зазначити, що одним із перших національних правових актів, який визначив стратегію інтеграції нашої країни до Европейського Союзу, став Указ Президента України від 11 червня 1998 року№ 615/98 «Про затвердження Стратегії інтеграції України до Свропейського Союзу», в якому зазначено, що адаптація законодавства України передбачає реформування ії правової системи та поступове приведення у відповідність із європейськими стандартами і охоплюе приватне, митне, трудове, фінансове, податкове законодавство, законодавство про інтелектуальну власність, охорону праці, охорону життя та здоров'я, навколишне природне середовище, захист прав споживачів, технічні правила і стандарти, транспорт, а також інші галузі, визначені Угодою про партнерство та співробітництво. Важливим чинником реформування правової системи України слід вважати участь України у конвенціях Ради Европи, які встановлюють спільні для цієї організації та Європейського Союзу стандарти $[3$, c. $20 ; 4]$.

У багатьох країнах Свропи поряд з головною функцією прокуратури - здійсненням кримінального переслідування - значна увага приділяється захисту прав та свобод громадян і інтересів держави у суді. Реагування органів прокуратури в порядку представництва інтересів громадянина або держави в суді широко практикується у країнах СНД (зокрема, Російській Федерації, Білорусі, Казахстані).

Згідно зі статтями 4 і 23 Закону «Про прокуратуру», організація та діяльність прокуратури України, статус прокурорів визначаються Конституцією України, цим та іншими законами України, чинними міжнародними договорами, згода на обов'язковість яких надана Верховною Радою України. Представництво прокурором інтересів громадянина або держави в суді полягає у здійсненні процесуаль- них та інших дій, спрямованих на захист інтересів громадянина або держави, у випадках та порядку, встановлених законом. Прокурор здійснює представництво в суді інтересів громадянина (громадянина України, іноземця або особи без громадянства) у випадках, якщо така особа не спроможна самостійно захистити свої порушені чи оспорювані права або реалізувати процесуальні повноваження через недосягнення повноліття, недієздатність або обмежену дієздатність, а законні представники або органи, яким законом надано право захищати права, свободи та інтереси такої особи, не здійснюють або неналежним чином здійснюють їі захист [2].

Така діяльність органів прокуратури передбачена законодавством і у країнах Свросоюзу - Бельгії, Болгарії, Аатвії, Литві, Польщі, Португалії, Словаччині, Угорщині, Іспанії, Франції. Так, відповідно до ст. 127 Конституції Болгарії прокуратура в установлених законом випадках бере участь у цивільних та адміністративних справах. У цивільному судочинстві Болгарії прокурор може виконувати свої завдання в таких процесуальних формах: а) порушення процесу на захист цивільних прав; б) вступ у вже розпочате цивільне провадження у справі; в) оскарження рішень, ухвал або виконавчих дій; г) звернення з пропозицією про перегляд рішення в порядку нагляду [5, с. 109-110].

Участь прокурора у цивільному судочинстві відповідно до чинного законодавства Франції обов'язкова при розгляді всіх справ з питань громадянства; справ із захисту інтересів неповнолітніх, коли виникає загроза їх здоров'ю, безпеці або освіті; справ із захисту прав та інтересів інвалідів; справ щодо захисту інтересів осіб з психічними вадами; справ щодо деяких питань у сфері комерційної діяльності (дотримання законності при реалізації майна фірми, яка визнана банкрутом); справ, у яких вирішуються питання державного значення.

У Литві прокурори беруть участь у цивільному процесі як самостійна сторона і сприяють пошуку об'єктивної істини як представники держави 3 питань захисту інтересів громадянина та суспільства. Передбачена участь прокурора у процесах з цивільного, трудового, адміністративного та економічного права і 
у законі «Про прокуратуру Республіки Угорщина» [6, с. 87-94].

Відповідно до ст. 3 Закону Республіки Польща від 20 червня 1985 року «Про прокуратуру» за прокурором закріплено повноваження пред'явлення позовів у карних та цивільних справах, а також подання клопотань і участь у судовому розгляді у цивільних справах, справах у сфері трудових відносин і соціального страхування, якщо того вимагає охорона правопорядку, громадських інтересів, власності або прав громадян [7, 294-367]. Згідно зі ст. 2 Закону Аатвійської Республіки від 19 травня 1994 року «Про прокуратуру» до функціональних повноважень прокуратури віднесено захист прав і законних інтересів осіб та держави і в установлених законом випадках подання позовних і інших заяв, а також взяття участі у розгляді справ у судах [8]. Зазначене дає підстави стверджувати, що в європейському праві завдання прокурорів у цивільних і адміністративних процесах універсальні й полягають у захисті прав соціально вразливих категорій громадян.

Зауважимо, що у розвинених країнах Европи історично склалися могутні саморегулятори громадянського суспільства, функціонує стабільне законодавство, діють вікові традиції поваги до закону; всі структури державного і соціального механізму характеризуються високою правовою культурою. I все-таки, незважаючи на це, для європейських держав продовжує залишатися актуальним здійснення прокуратурою повноважень поза межами кримінальної сфери. Україна робить лише перші кроки на шляху до євроінтеграції, проводяться реформи судової і правоохоронної систем, і на цьому етапі вкрай важливо забезпечити ефективну діяльність органів прокуратури щодо представництва інтересів громадянина або держави в суді.

Від принципової позиції прокурора у підготовці позовної заяви, участі в судовому процесі щодо захисту інтересів держави та при виконанні судових рішень залежить рівень відшкодування збитків, заподіяних державі. Прокурор, представляючи інтереси держави в суді, відстоює економічні та інші державні інтереси, які порушуються внаслідок протиправних дій (бездіяльності) фізичних або юридичних осіб. У разі, якщо суб'єкт владних повноважень не здійснює чи неналежним чином здійснює захист законних інтересів держави або якщо він відсутній, а також у разі представництва інтересів громадянина 3 метою встановлення наявності підстав для представництва, прокурор має право витребовувати копії документів, матеріалів і пояснення від посадових осіб органів державної влади, органів місцевого самоврядування, військових частин, державних та комунальних підприємств, установ і організацій, органів Пенсійного фонду України та фондів загальнообов'язкового державного соціального страхування [9, с. 30].

Правовий аналіз норм чинного процесуального законодавства дає можливість зробити висновок про те, що прокурора віднесено до осіб, яким законом надано право захищати права, свободи та інтереси інших осіб - котрі входять до складу осіб, які беруть участь у справі (ч. 3 ст. 26 та ст. 45 ЦПК України [38]), або до складу учасників судового процесу (ч. 1 ст. 18, ст. 29 ГПК України [10]), до осіб, яким законом надано право захищати права, свободи та інтереси інших осіб (ст. 60 КАС України [11]). Отже, при здійсненні процесуальних форм реалізації функції представництва прокурор набуває процесуального статусу зазначених учасників судового процесу. Необхідно зауважити, що доктринальне дослідження процесуальної природи представництва прокурором інтересів громадянина або держави в суді та його характерних ознак визначається високим рівнем дискусійності, що переважною мірою зводиться до виокремлення особливостей представництва прокурором інтересів громадянина або держави в суді у порівнянні з іншими видами представництва. Такий рівень дискусійності багато у чому обумовлений позицією Конституційного Суду України, яку він обійняв у рішенні в справі про представництво прокуратурою України інтересів держави в арбітражному суді, де зазначено, що представництво прокуратурою України інтересів держави в суді є одним із видів представництва в суді, яке відрізняється від інших видів представництва рядом специфічних ознак: складом представників та колом суб'єктів, інтереси яких вони представляють, обсягом повноважень, формами їх реалізації. У подальшому різноманіття наукових поглядів 3 цього 
питання умовно можна звести до декількох основних напрямів.

Так, представники першого напряму розглядають представництво прокурором інтересів у суді як процесуальне представництво у справі з притаманними йому ознаками, яке мало чим відрізняється від класичного процесуального представництва [12, с. 73]. Аналізуючи вказані правові погляди, вважаємо слушною думку науковців, які не погоджуються 3 такою позицією i, зокрема, зазначають, що відмінність між правовим статусом адвоката як повіреного юридичної особи, громадянина і прокурора в тому, що прокурор завжди є представником так званої публічної влади.

Представники іншого напряму розглядають представництво прокурором інтересів у суді як особливий підвид представництва за законом. Одним із аргументів, яким окремі представники цієї концепції обгрунтовують своє бачення, є позиція Верховного суду України, яку він зайняв у Постанові від 2 березня 2010 р. по справі № 21-2368во09, у якій, зокрема, вказав, що прокурор в адміністративному судочинстві здійснюе законне представництво, особливість якого полягає у тому, що законний представник самостійно (без доручення), на підставі закону здійснює процесуальні права та обов'язки сторони чи третьої особи, яку він представляє, діючи в іiі інтересах, що, однак, не впливає на загальні правила представництва [13].

Досліджуючи це питання, деякі науковці розглядають процесуальний статус прокурора щодо реалізації функції представництва інтересів громадянина або держави в суді, прирівнюючи його фактично до процесуального статусу сторони в процесі. Основними аргументами прихильників цієї точки зору є те, що прокурор, який заявив позов або вступив у справу, є перш за все суб'єктом доказування, який володіє такими ж процесуальними правами, що і суб'єкти спірних правовідносин, а також обов'язками щодо правильного визначення предмету спору та доказування своєї правової позиції [14, с. 29-30]. Доречно зауважити, що до таких висновків до певної міри підштовхує і законодавець, визначаючи у ч. 4 ст. 23 Закону України «Про прокуратуру» (2014 р.) про те, що у разі підтвердження судом наявності підстав для представництва прокурор користується процесуальними повноваженнями відповідної сторони процесу [1, с. 116].

Отже, представництво прокурором інтересів громадянина в суді повинно мати місце лише тоді і саме тоді, коли особа не спроможна самостійно реалізувати право на судовий захист своїх прав, свобод і законних інтересів.

Згідно зі ст. 23 Закону України «Про прокуратуру» представництво прокурором інтересів громадянина або держави в суді полягає у здійсненні процесуальних та інших дій, спрямованих на захист інтересів громадянина або держави, у випадках та порядку, встановлених законом. Прокурор здійснює представництво в суді інтересів громадянина (громадянина України, іноземця або особи без громадянства) у випадках, якщо така особа не спроможна самостійно захистити свої порушені чи оспорювані права або реалізувати процесуальні повноваження через недосягнення повноліття, недієздатність або обмежену дієздатність, а законні представники або органи, яким законом надано право захищати права, свободи та інтереси такої особи, не здійснюють або неналежним чином здійснюють їі захист.

При цьому у Законі зазначено, що прокурор здійснює представництво в суді інтересів не тільки громадянина України, а й іноземця або особи без громадянства, але залишає поза увагою законність перебування їх на території України. 3 цього приводу слід звернути увагу на трактування ст. 1 Закону України «Про звернення громадян», у якій встановлено, що особи, які не є громадянами України і законно знаходяться на ії території, мають таке саме право на подання звернення, як і громадяни України [9, с. 31].

Відповідно до зазначених правових норм Закону України «Про прокуратуру» прокурор здійснює представництво в суді законних інтересів держави у разі порушення або загрози їх порушення, якщо захист цих інтересів не здійснює або неналежним чином здійснює орган державної влади, орган місцевого самоврядування чи інший суб'єкт владних повноважень, до компетенції якого віднесені відповідні повноваження, а також у разі відсутності такого органу. При цьому не допускається здійснення прокурором представництва в 
суді інтересів держави в особі державних компаній, а також у правовідносинах, пов'язаних iз виборчим процесом, проведенням референдумів, діяльністю Верховної Ради України, Президента України, створенням та діяльністю засобів масової інформації, а також політичних партій, релігійних організацій, організацій, що здійснюють професійне самоврядування, та інших громадських об'єднань. Представництво в суді інтересів держави в особі Кабінету Міністрів України та Національного банку України може здійснюватися прокурором Генеральної прокуратури України або регіональної прокуратури тільки за письмовою вказівкою чи наказом Генерального прокурора України, його першого заступника чи заступника відповідно до компетенції.

3 метою однакового застосування судами поняття «інтереси держави» у рішенні Конституційного Суду України від 8 квітня 1999 року у справі № 1-1/99 щодо офіційного тлумачення положень ст. 2 Господарського процесуального кодексу України встановлено, що «інтереси держави» 6 оціночним поняттям, прокурор чи його заступник у кожному конкретному випадку самостійно визначають, 3 посиланням на законодавство, на підставі якого подається позов, у чому саме відбулося чи може відбутися порушення матеріальних або інших інтересів держави, обгрунтовує у позовній заяві необхідність їх захисту та зазначає орган, уповноважений державою здійснювати відповідні функції у спірних відносинах. Таким органом може бути орган державної влади чи орган місцевого самоврядування, якому законом надано повноваження органу виконавчої влади [9, с. 33].

Отримання письмової згоди фактично є наданням громадянином, законним представником або відповідними органами звернення до прокуратури про захист права особи в порядку представництва.

Прокурору для реагування в порядку представництва відповідно до Закону України від 14 жовтня 2014 року «Про прокуратуру» необхідно мати чотири підстави: поперше, наявність факту порушення прав, свобод та законних інтересів громадянина або законних інтересів держави; по-друге, особа потребує захисту саме у випадках, ви- значених законом, законні представники або відповідні органи при цьому не здійснюють або неналежно здійснюють його, а захист інтересів держави не здійснює або неналежно здійснює відповідний орган державної влади чи суб'єкт владних повноважень або він відсутній; по-третє, те, що перед зверненням до суду прокурор зобов'язаний повідомити про це громадянина, законного представника або відповідний суб'єкт владних повноважень, які мають право оскаржити наявність підстав для представництва або надати згоду на це; почетверте, підтвердження судом підстав для представництва.

Форми представництва прокурором інтересів громадянина або держави у суді деталізовані у ст. 23 зазначеного Закону, у якій встановлено, що під час здійснення представництва інтересів громадянина або держави у суді прокурор має право в порядку, передбаченому процесуальним законом та законом, що регулює виконавче провадження:

1) звертатися до суду з позовом (заявою, поданням);

2) вступати у справу, порушену за позовом (заявою, поданням) іншої особи, на будьякому етапі судового провадження;

3) ініціювати перегляд судових рішень, у тому числі у справі, порушеній за позовом (заявою, поданням) іншої особи;

4) брати участь у розгляді справи;

5) подавати цивільний позов під час кримінального провадження у випадках та порядку, визначених кримінальним процесуальним законом;

6) брати участь у виконавчому провадженні при реалізації рішень у справі, в якій прокурором здійснювалося представництво інтересів громадянина або держави в суді.

Прокурор, який бере участь у розгляді справ у судах, дотримуючись принципу незалежності суддів і додержання закону, слідкує за виконанням вимог про всебічний, повний і об'єктивний розгляд справи та постановленням судового рішення, що грунтується на законі. Прокурор може вступити у справу на будь-якій стадії процесу, якщо цього вимагає захист конституційних прав громадян та інтересів держави. Прокурор має рівні права $з$ іншими учасниками судового засідання. Обсяг і межі повноважень прокурора, який 
бере участь у судовому процесі, визначаються Законом України «Про прокуратуру» та процесуальним законодавством України [9, с. 33].

Відповідно до зазначених правових норм Закону України «Про прокуратуру» прокурор здійснює представництво в суді законних інтересів держави у разі порушення або загрози їх порушення, якщо захист цих інтересів не здійснює або неналежним чином здійснює орган державної влади, орган місцевого самоврядування чи інший суб'єкт владних повноважень, до компетенції якого віднесені відповідні повноваження, а також у разі відсутності такого органу. При цьому не допускається здійснення прокурором представництва в суді інтересів держави в особі державних компаній, а також у правовідносинах, пов'язаних iз виборчим процесом, проведенням референдумів, діяльністю Верховної Ради України, Президента України, створенням та діяльністю засобів масової інформації, а також політичних партій, релігійних організацій, організацій, що здійснюють професійне самоврядування, та інших громадських об'єднань. Представництво в суді інтересів держави в особі Кабінету Міністрів України та Національного банку України може здійснюватися прокурором Генеральної прокуратури України або регіональної прокуратури тільки за письмовою вказівкою чи наказом Генерального прокурора України, його першого заступника чи заступника відповідно до компетенції.

3 метою однакового застосування судами поняття «інтереси держави» у рішенні Конституційного Суду України від 8 квітня 1999 року у справі № 1-1/99 щодо офіційного тлумачення положень ст. 2 Господарського процесуального кодексу України встановлено, що «інтереси держави» $є$ оціночним поняттям, прокурор чи його заступник у кожному конкретному випадку самостійно визначає, з посиланням на законодавство, на підставі якого подається позов, у чому саме відбулося чи може відбутися порушення матеріальних або інших інтересів держави, обгрунтовує у позовній заяві необхідність їх захисту та зазначає орган, уповноважений державою здійснювати відповідні функції у спірних відносинах. Таким органом може бути орган державної влади чи орган місцевого самоврядування, якому законом надано повноваження органу виконавчої влади [9, с. 32].

\section{Висновки}

Підводячи підсумок вищевикладеному, необхідно виділити найбільш характерні ознаки представництва прокурором інтересів громадянина або держави в суді, які відрізняють його від договірного або законного представництва. По-перше, відповідно до ст. 23. Закону України «Про прокуратуру» прокуратура - це самостійний інститут влади, який не належить до жодної з гілок влади. Одним із головних завдань прокуратури як правозахисного органу є захист приватних i публічних інтересів. Так, відповідно до ч. 1 ст. 23 прокуратура здійснює представництво інтересів громадянина або держави від імені держави. Саме тому прокурор як учасник судового процесу має особливий правовий стаTyc.

\section{Література}

1. Стефанчук М.М. Напрями вдосконалення процесуального статусу прокурора як суб'єкта реалізації функції представництва інтересів громадянина або держави в суді.Науковий вісник Ужгородсъкого національного університету. 2015. № 2. C. 115-121.

2. Про прокуратуру: Закон України від 14 жовтня 2014 р. № 1697-VII. Голос Украйни. 2014. № 206.

3. Драган О. Представництво прокурором інтересів громадянина та держави в суді в умовах європейської інтеграції України. Науковий часопис Національної академӥ прокуратури України. 2016. № 1. С. 19-25.

4. Про затвердження Стратегії інтеграції України до Європейського Союзу: Указ Президента України від 11 червня 1998 року № 615/98. URL: http://zakon3.rada.gov.ua/laws/ show/615/98.

5. Дунас Т.О. Прокурор у цивільному процесі іноземних держав. Вісник прокуратури. 2003. № 7. С. 109-113.

6. Грицаєнко А.Р. Прокуратура в країнах Європи: навч. посіб. К.: Біноватор, 2006. $130 \mathrm{c}$.

7. Статус органів публічного обвинувачення: міжнародні стандарти, зарубіжне законодавство і пропозиції щодо реформування 


\section{АНОТАЦІЯ}

у статті проаналізовано законодавче закріплення функий представництва прокуратурою інтересів громадянина або держави в суді у країнах СНД та Евросоюзу. Розглянуто зміни підстав $i$ порядку здійснення прокурором представнищької діяльності згідно із Законом Украӥни «Про прокуратуру» від 14 жовтня 2014 року.

Зроблено висновок, шо функиія представництва, якою наділена прокуратура України, в сучасних умовах $є$ иілком обгрунтованою та виправданою, про що свідчать результати багаторічної практичної діяльності прокурора iз захисту прав громадян та інтересів держави в суdi.

Наголошено, що у багатьох краӥнах Европи поряд з головною функиією прокуратури - здійсненням кримінального переслідування - значна увага приділяється захисту прав та свобод громадян і інтересів держави у суді. 3окрема, така діяльність органів прокуратури передбачена законодавством у країнах Евросоюзу - Бельгї, Болгаріі, Аатвї, Аитві, Польщз, Португалї, Словаччині, Угорщині, Іспанї, Франиій. Вказана діяльність ијілком відповідає європейським правовим традиціям захисту прав і свобод людини у краӥнах Свропейсъкого Союзу.

Ключові слова: прокуратура, захист прав, бункиї, представництво інтересів, громадяни, держава, суд.

в Україні / за заг. ред. О.А. Банчука. К.: Атіка, 2012. 624 c.

8. Про прокуратуру: Закон Аатвійської Республіки від 19 травня 1994 року. URL: http://www.pravo.lv/likumi/56_zoprt.html.

9. Безкровний $\mathrm{E}$. Представництво прокурором інтересів громадянина або держави у суді в сучасних умовах. Науковий часопис Національноїакадемії прокуратури Украӥни. 2016. № 2. Ч. 1. C. 28-36 URL: http://www.chasopysnapu.gp.gov.ua/chasopys/ua/pdf/10-2016/01/bezkrovnyj.pdf

10. Господарський процесуальний кодекс України від 6 листопада 1991 року № 1798-
The article analyzes the legislative consolidation of the function of representation by the prosecutor's office of the interests of a citizen or the state in court in the CIS and the European Union. Changes in the grounds and procedure for the prosecutor's representative activity in accordance with the Law of Ukraine "On the Prosecutor's Office» of October 14, 2014 are considered.

It is concluded that the function of representation, which is endowed with the Prosecutor's Office of Ukraine, in modern conditions is quite reasonable and justified, as evidenced by the results of many years of practical work of the prosecutor to protect the rights of citizens and the interests of the state in court.

It is emphasized that in many European countries, along with the main function of the prosecutor's office - the prosecution - much attention is paid to protecting the rights and freedoms of citizens and the interests of the state in court. In particular, such activity of prosecutor's offices is provided by the legislation in the countries of the European Union - Belgium, Bulgaria, Latvia, Lithuania, Poland, Portugal, Slovakia, Hungary, Spain, France. These activities are fully consistent with European legal traditions of human rights and freedoms in the European Union.

Key words: prosecutor's office, protection of rights, functions, representation of interests, citizens, state, court.

XII (зі змінами та доповненнями). Відомості Верховної Ради Украӥни. 1992. № 6. Ст. 56.

11. Кодекс адміністративного судочинства України від 6 липня 2005 р. № 2747-VI (зі змінами та доповненнями). Відомості Верховной Ради Украӥни. 2005. №№ 35-36, 37. Ст. 446.

12. Задніпровський О. Права прокурора у світлі нової Конституції України. Право Украӥни. 1997. № 1. С. 72-73, 110.

13. Постанова Верховного Суду України від 2 березня 2010 р. у справі № 21-2368 URL: www.reyestr.court.gov.ua.

14. Заболоцкая И.В. Доказательная деятельность прокурора. Закон и право. 2000.№ 1. С. 29-30. 